$1-2013$

\title{
Are Oil, Gold and the Euro Inter-Related? Time Series and Neural Network Analysis
}

Anastasios G. Malliaris

Loyola University Chicago, tmallia@luc.edu

Mary Malliaris

Loyola University Chicago

Follow this and additional works at: https://ecommons.luc.edu/business_facpubs

Part of the Business Commons

\section{Author Manuscript}

This is a pre-publication author manuscript of the final, published article.

\section{Recommended Citation}

Malliaris, Anastasios G. and Malliaris, Mary. Are Oil, Gold and the Euro Inter-Related? Time Series and Neural Network Analysis. Review of Quantitative Finance and Accounting, 40, 1: 1-14, 2013. Retrieved from Loyola eCommons, School of Business: Faculty Publications and Other Works, http://dx.doi.org/ 10.1007\%2Fs11156-011-0265-9

This Article is brought to you for free and open access by the Faculty Publications and Other Works by Department at Loyola eCommons. It has been accepted for inclusion in School of Business: Faculty Publications and Other Works by an authorized administrator of Loyola eCommons. For more information, please contact ecommons@luc.edu.

\section{cc) (†) $\ominus$}

This work is licensed under a Creative Commons Attribution-Noncommercial-No Derivative Works 3.0 License. (c) Springer International Publishing AG 2013 


\title{
ARE OIL, GOLD AND THE EURO INTER-RELATED? TIME SERIES AND NEURAL NETWORK ANALYSIS
}

\author{
A.G. Malliaris \\ Mary Malliaris \\ Loyola University Chicago \\ School of Business Administration \\ 1 East Pearson Street \\ Chicago, Illinois 60611 \\ TMALLIA@LUC.EDU \\ MMALLIA@LUC.EDU
}

\begin{abstract}
This paper investigates inter-relationships among the price behavior of oil, gold and the euro using time series and neural network methodologies. Traditionally gold is a leading indicator of future inflation. Both the demand and supply of oil as a key global commodity are impacted by inflationary expectations and such expectations determine current spot prices. Inflation influences both short and long-term interest rates that in turn influence the value of the dollar measured in terms of the euro. Certain hypotheses are formulated in this paper and time series and neural network methodologies are employed to test these hypotheses. We find that the markets for oil, gold and the euro are efficient but have limited inter-relationships among themselves.
\end{abstract}

Key Words: Oil, Gold, the Euro, Relationships, Time-series Analysis, Neural Network Methodology

\section{JEL Classification: G14, G15, Q41}

Current Revised Version: November 28, 2011. An earlier version was presented at the Joint Athenian Policy Forum and the Indian Institute of Management Kozhikode Conference, Calicut, India, December 18-20, 2008. We are thankful to Joko Mulyadi for data collection, bibliographical search and computational assistance. Valuable comments were given by Bala Batavia, Marc Hayford and several conference participants. We are also grateful to anonymous referees of the Review of Quantitative Finance and Accounting for valuable comments during two substantial revisions that helped us improve considerably this version and to Professor C. F. Lee, Editor-In-Chief for great encouragement and support.

This paper has been accepted for publication in the Review of Quantitative Finance and Accounting 


\title{
ARE OIL, GOLD AND THE EURO INTER-RELATED? TIME SERIES AND NEURAL NETWORK ANALYSIS
}

\begin{abstract}
This paper investigates inter-relationships among the price behavior of oil, gold and the euro using time series and neural network methodologies. Traditionally gold is a leading indicator of future inflation. Both the demand and supply of oil as a key global commodity are impacted by inflationary expectations and such expectations determine current spot prices. Inflation influences both short and long-term interest rates that in turn influence the value of the dollar measured in terms of the euro. Certain hypotheses are formulated in this paper and time series and neural network methodologies are employed to test these hypotheses. We find that the markets for oil, gold and the euro are efficient but have limited inter-relationships among themselves.
\end{abstract}

\section{Introduction}

This paper studies the inter-relationships between three important markets: oil, gold and the euro during 2000-2007. There are two approaches to such a study. First, one can use a microeconomic methodology to determine the price formation in these three markets and investigate factors affecting the demand, supply and market structure. Second, one can follow a macroeconomic methodology by investigating statistical inter-relationships among these three markets. This second approach is the one we have chosen because we are investigating financial interrelationships in the global markets for oil, gold and the euro.

The reason for selecting this approach is our interest in searching for statistical and financial linkages between these three markets. Such linkages may lead to arbitrage 
opportunities and appropriate trading strategies. For example, it is reasonable to argue that increases in the price of oil (due to say, increased demand from a rapidly growing country such as India or China) contribute to inflationary concerns that may cause the price of gold to also increase. Gold prices often anticipate future inflation as well as supply and demand fundamentals for this precious metal. If oil prices increase and gold prices also increase, economic analysis suggests that interest rates will also increase. If the U.S. Federal Reserve follows an easy monetary policy in order to sustain economic growth relative to the European Central Bank, it is reasonable to argue that the U.S. dollar will depreciate in comparison to the euro.

In section 2, we introduce some hypotheses about the relationship between oil, gold, and the euro. In particular we observe that a depreciation of the U.S. dollar against the euro may generate fears of global inflation for countries that peg their currency to the dollar and induce oil producing countries to demand compensation for their oil. In turn, such appreciation in the price of oil may fuel increases in the price of gold. These ideas are formulated in detail in section 2.

In section 3, we provide a brief overview of these three markets and highlight that the hypothesized relationships did not exist prior to 1999 , simply because the euro is a very recent creation. We then proceed to describe our data in section 4 and test our hypotheses using both time series and neural network methods in sections 5 and 6 . Our conclusions are summarized in section 7.

\section{Hypotheses}


The euro was created on January 1, 1999 and, in a relatively short period since its creation, has challenged the U.S. dollar for global currency leadership. Currently the euro is considered to be the second most important global currency after the U.S. dollar, followed by the Japanese yen and the British pound. Some authors, such as Chinn and Frankel (2008) claim that the euro may actually challenge the dollar in the longrun. Kondonassis, Paraskevopoulos and Malliaris (2007) provide data to show that among global currencies, about $60 \%$ of global transactions are conducted in U.S. dollars, $20 \%$ in euros, $5 \%$ in yen and also $5 \%$ in British pounds. Oil, gold and most major energy, metal and agricultural markets are all transacted in U.S. dollars.

We initially investigate the efficiency of these three markets. In view of the fact that all three markets are very actively traded across the globe, we expect any publically available information to be quickly incorporated and reflected in the prices. So, we hypothesize that these three markets are efficient in the semi-strong sense. We wish, however, to go beyond market efficiency and investigate what, if any, relationships exist between oil, gold, and the euro? From an efficient markets hypothesis perspective each of these markets responds quickly to newly arrived information relevant to this particular market. However, from a general equilibrium perspective, important relationships may exist among these three markets.

We first, hypothesize that all three follow the standard random walk hypothesis because these are traded in highly efficient global markets. We also go beyond to argue that these markets may be economically linked. In particular, we argue that oil price increases are an important source of commodity inflation that contributes to increases in the price of gold because gold is considered to be a general hedge against inflation. We 
hypothesize that if oil supply disruptions and/or increases in the demand for oil, primarily from large emerging economies such as India, China and Brazil, contribute to oil price increases, these in turn will also influence the price of gold in some measure.

We also hypothesize that increases in the price of gold, independent of its relationship to oil, may signal inflationary expectations and cause oil producing countries to seek increases in the price of oil. In addition, we claim that since both oil and gold are globally traded in U.S. dollars, increases in the prices of oil and gold measured in dollars will reflect a strengthening of the euro, unless concurrently the euro weakens in terms of the U.S. dollar for reasons unrelated to gold or oil. Furthermore, the interest in the financial behavior of the euro is motivated by the fact that the euro is now the second most dominant global currency after the U.S. dollar as reported in Kondonassis, Paraskevopoulos and Malliaris (2007). Thus, the global currency competition between the dollar and the euro implies that a weakening of the U.S. dollar is expressed as an increase in the price of a euro in terms of dollars.

For the purpose of an illustration, let the price of oil per barrel be $\$ 50$, the price of gold per ounce $\$ 500$ and the euro be $\$ 1.20$. Suppose oil increases to $\$ 55$ and gold increases to $\$ 525$. Economic reasoning would argue that in response to the price changes of oil and gold, currency prices will also change. In view of the convention that oil and gold are traded globally in U.S. dollars, as oil and gold producing countries observe price increases in oil and gold they may demand further compensation if the U.S. dollar depreciates in terms of the euro. Thus, commodity prices influence the euro but conversely, a strengthening of the euro in terms of U.S. dollars may also induce an increase in the price of oil and gold. Of course, currencies respond to several other factors 
such as national and global interest rates, inflationary expectations and general economic prospects. We hypothesize that the euro is more sensitive to oil than gold because energy is a component of price indices measuring inflation.

These hypotheses propose possible economic and financial linkages between these three markets that have not been studied in the literature, primarily because the euro is a new financial innovation. The markets for oil and gold have been extensively studied but we attempt here to bring together these three markets and use recent methodologies to uncover emerging relationships. Carpenter (2004) in Forbes and Hanke (2007) in Bloomberg discuss possible linkages among these three markets and give their reasons. For example, Hanke (2008) claims that easy monetary policies by the Fed during 2003-07 fueled increases in the price of oil and gold and weakness in the U.S. dollar as reflected in the appreciation of the euro.

\section{Brief Review of the Literature}

Bordo, Dittmar and Gavin (2007) and several other authors earlier such as Aliber (1966), Barro (1979), Bordo (1981), Goodfriend (1988), Eichengreen (1992), Bordo and Kydland (1995), Fujiki (2003), and Canjels, Prakash-Canjels, among numerous others, have presented various aspects of the role of the gold standard as a global monetary system. These studies document the role of gold in preserving price stability. When economists discuss the classical gold standard as a monetary system that has been associated with price stability, the emphasis is always on the long run. Short-term price variability occurred often due to real shocks to the economy but adhering to the gold 
standard ensured overall long-run price stability. The main disadvantage of the gold standard was its cost in terms of constraining real economic growth.

Independent of anchoring the global monetary system on gold, after August 15, 1971, the metal ceased its association with global monetary matters but maintained its property as an indicator of inflation. Diba and Grossman (1984) argued theoretically and investigated empirically whether the price of gold exhibits rational bubbles. They concluded that the empirical analysis finds a close correspondence between the time series properties of the relative price of gold and the time series properties of real interest rates. Theoretically, real interest rates are a proxy for the fundamental component of the relative price of gold. The authors conclude the evidence is consistent with the combined hypotheses that the relative price of gold corresponds to market fundamentals, that the process generating first differences of market fundamentals is stationary, and that actual price movements do not involve rational bubbles.

From 1982 to 2005, the spot price of gold per ounce fluctuated between $\$ 250$ and $\$ 500$. During the years $2005-07$, the price of gold skyrocketed to over $\$ 1,000$. Can we say that such an increase foretells great future inflation or has gold's property of being a hedge against inflation been replaced by some other property?

With regard to oil, we can organize the large literature into microeconomic and macroeconomic studies. Representative of the first approach is the recent study of Elekdag, Lalonde, Laxton, Muir and Pesenti (2008) that develops a five-region model of the global economy and considers various scenarios to study the implications of different shocks driving oil prices worldwide. The model introduces significant real adjustment costs in the energy sector, making both the demand and supply for crude oil extremely 
inelastic in the short run, thus requiring large movements in crude oil prices to clear the energy market.

To answer the question about the underlying causes of the oil price run-up since 2003, the authors offer a story based on stronger productivity growth in oil importing regions coupled with shifts in oil intensity in production (emerging Asia), and (to a much lesser extent) pure price increases by oil producers. Oil price shocks stemming from higher growth in the oil-importing regions are accompanied by wealth transfers through terms-of-trade movements, leading consumption to grow slower than output in the oilimporting regions. In the medium term, high investment rates in the high-growth regions crowd out investment in the oil-exporting regions. These results need not hold if higher oil prices bring about expectations of a larger availability of oil reserves in the future. Moreover, the positive effects of higher oil prices on consumption need not translate into reduced current account surpluses in the oil-exporting regions, to the extent that they are accompanied by an upward shift in the desired net foreign asset positions. The conclusions about the role of increased productivity in the oil-importing regions can be reinforced by considering emerging Asia in particular, with its increased intensive use of oil in the production of tradable goods.

Henning and Shaw (2000) study the microeconomic market structure of oil and gas markets. They study differences in oil and gas market values and provide explanations due to risk differences. Lin and Duan (2007) analyze the oil convenience yields estimated under supply and demand shocks and find that oil prices and convenience yields follow seasonal patterns. 
The second approach assesses the macroeconomic impact of the oil sector on the economy. Earlier, Hamilton (1983, 1996), Hooker (1996, 2002), Bernanke, Gertler and Watson (1997) and Finn (2000) and more recently Blanchard and Gali (2007), Herrera and Pesavento (2007), Mileva and Siegfried (2007), Nakov and Pescatori (2007), and Kilian (2008) have studied various implications of the price of oil on the U.S. economy, inflation and monetary policy. The existing literature on oil has reached several broad conclusions from these studies. First, the effects of oil price shocks have changed over time, with steadily smaller effects on prices and wages, as well as on output and employment. In other words, the energy sector remains significant but its macroeconomic impact has steadily declined over the last two decades. In particular, the decrease in the share of oil in consumption and in production has declined enough to have quantitatively significant implications. Second, the increased credibility of monetary policy during the Great Moderation period of 1984 to 2007 has contributed to the decline of inflationary expectations and the impact of oil shocks.

In contrast to these issues addressed in the existing literature we consider the question: Are increases in the prices of oil related to the appreciation of the euro and gold?

With respect to the euro, in a matter of a few years, a very large bibliography has emerged that describes the creation of this new global currency and its relative success. Portes and Rey (1998) offer a comprehensive background of the monetary history of the emergence of the euro while Chinn and Frankel (2005), Eichengreen (2007), and Bordo and James (2008) speculate on euro's future emergence as a competitor to the U.S. dollar. The euro initially weakened from 1999 to 2001, but has strengthened considerably 
against the U.S. dollar during 2002 to 2007. The euro's volatility appears to exhibit similar behavior of other leading currencies and is related to its volume of transactions as discussed in Bhar and Malliaris (1998).

This review of the literature illustrates that gold and oil have played important roles and have been studied essentially independent of one another. Gold has served as the anchor of the Global Monetary System known as the Gold Standard. Since the introduction of the euro and in particular during the 2000-07 period, the euro, gold and oil appear to be interrelated. We claim in the hypotheses listed in section 2 that the weakness of the U.S. dollar as measured by the appreciation of the euro from about $\$ .80$ per euro to $\$ 1.55$ per euro during the pre-crisis period $2000-07$ is partially inter-related both to the price of oil moving from about $\$ 20$ per barrel to $\$ 110$ and the price of gold from about $\$ 300$ to over $\$ 1,000$. Thus, unlike the existing literature that has studied the markets for oil, gold and the euro independent of each other, we propose in the hypotheses stated earlier to study the impacts of these markets on each other.

\section{Data}

We use daily spot prices for gold, oil, and the euro. The data sample covers the time period from January 4, 2000 through December 31, 2007 and was downloaded from Bloomberg. There are a total of 2,031 observations for prices for each of the three daily closing prices. During this time all three series experienced great movement, the price of oil varied from $\$ 17.45$ to $\$ 98.18$; gold had a low of $\$ 255.10$ and a high of $\$ 839.60$; and the Euro moved from $\$ 0.83$ to $\$ 1.49$. For analysis, all data was transformed into natural logarithms of the raw data.

\section{Time Series Methodology and Results}


The hypotheses stated above are tested with two complementary methodologies. We first employ in this section time series analysis such as the augmented Dickey and Fuller tests of stationarity and tests of cointegration and then we follow neural network methodologies.

Figure 1 shows the natural logarithm of the three data series.

\section{Figure 1}

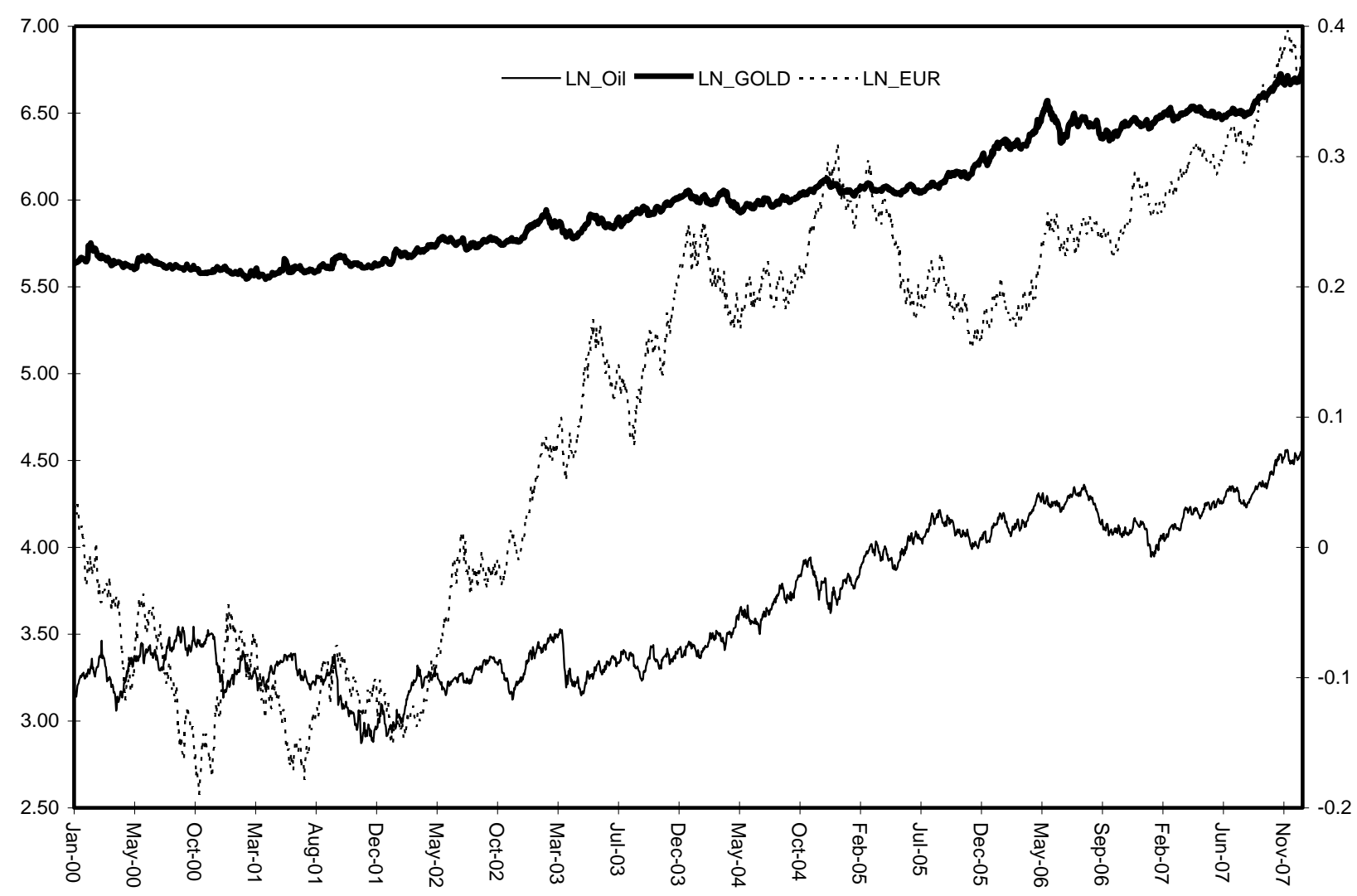

\section{Test of Stationarity}

The time series econometrics is described in detail in Enders (2010). According to this methodology, we need first to investigate the stationarity of our three series of data using the augmented Dickey and Fuller (ADF) (1979) test: 


$$
\Delta X_{t}=a_{0}+a_{1} \cdot t+a_{2} \cdot X_{t-1}+\sum_{i=1}^{T} c_{i} \cdot \Delta X_{t-i}+\varepsilon_{t}
$$

Where $X_{t}$ represents the logarithm of the price of the appropriate variable and is called the level of the variable. The null hypothesis of non-stationarity is $\mathrm{H}_{0}: a_{2}=0$. If the null hypothesis cannot be rejected for the level of the variable but is rejected for the first difference, then the variable is stationary in the first difference and it is said that the variable is integrated of order 1, denoted by I(1). Model (1) can be extended to include a constant and/or a trend as described in (1) and Table 1.

First, the natural logarithms of the prices of oil, gold and the euro follow random walks. These random walks are of three types: a random walk with no constant and no time trend, a random walk with a constant and a random walk with a constant and trend. We have also tested these three models with zero, five and twenty lags, the length of these lags having been decided by the Akaike criterion. While the log price levels of oil, gold and the euro follow three types of random walks, the hypotheses that their differences are also random walks is rejected in the lower level of Table 1. Thus we conclude that oil, gold and the euro are integrated of order one written as I(1). 
Table 1

Augmented Dickey-Fuller Tests of Stationary

Price Level $(L N(X))$

\begin{tabular}{|c|c|c|c|}
\hline & Only Lags & Lags and Constant & $\begin{array}{c}\text { Lags, Constant, } \\
\text { and Trend }\end{array}$ \\
\hline \multicolumn{4}{|l|}{ Gold } \\
\hline No lags & 2.361111 & 0.667188 & -2.836540 \\
\hline 5 lags & 2.363708 & 0.693961 & -2.843861 \\
\hline 20 lags & 2.373704 & 0.766124 & -2.862830 \\
\hline \multicolumn{4}{|l|}{ Oil } \\
\hline No lags & 1.191509 & -0.626496 & -2.759707 \\
\hline 5 lags & 1.313748 & -0.461972 & -2.541877 \\
\hline 20 lags & 1.368074 & -0.235474 & -2.456710 \\
\hline \multicolumn{4}{|l|}{ Euro } \\
\hline No lags & 0.631741 & -0.079099 & -3.034661 \\
\hline 5 lags & 0.659061 & -0.049944 & -3.063701 \\
\hline 20 lags & 0.521473 & -0.293593 & -2.657669 \\
\hline
\end{tabular}

First Price Differences $\left(L N\left(X_{t}\right)-L N\left(X_{t-1}\right)\right)$

\begin{tabular}{|c|c|c|c|}
\hline & Only Lags & Lags and Constant & $\begin{array}{l}\text { Lags, Constant, } \\
\text { and Trend }\end{array}$ \\
\hline \multicolumn{4}{|l|}{ Gold } \\
\hline No lags & -46.65579 & -46.77877 & -46.81729 \\
\hline 5 lags & -18.68709 & -18.86720 & -18.93417 \\
\hline 20 lags & -9.389532 & -9.698579 & -9.833956 \\
\hline \multicolumn{4}{|l|}{ Oil } \\
\hline No lags & -45.22329 & -45.25046 & -45.24871 \\
\hline 5 lags & -19.52137 & -19.57521 & -19.58983 \\
\hline 20 lags & -10.21073 & -10.31103 & -10.35710 \\
\hline \multicolumn{4}{|l|}{ Euro } \\
\hline No lags & -46.05127 & -46.07716 & -46.10367 \\
\hline 5 lags & -17.92471 & -17.97228 & -18.02022 \\
\hline 20 lags & -9.111516 & -9.214248 & -9.259299 \\
\hline
\end{tabular}

The model is $\Delta X_{t}=a_{0}+a_{1} \cdot t+a_{2} \cdot X_{t-1}+\sum_{i=1}^{T} c_{i} \cdot \Delta X_{t-i}+\varepsilon_{t} \quad$ The null hypothesis is $\mathrm{H}_{0}: a_{2}=0$ (variable is not stationary). MacKinnon critical values are:

\begin{tabular}{|c|c|c|c|}
\hline Only Lags & $\begin{array}{c}\text { Lags and } \\
\text { Constant }\end{array}$ & $\begin{array}{c}\text { Lags, Constant, } \\
\text { and Trend }\end{array}$ \\
\hline
\end{tabular}




\begin{tabular}{|l|l|l|l|}
\hline $1 \%$ & -2.58 & -3.43 & -3.96 \\
$5 \%$ & -1.95 & -2.86 & -3.41 \\
$10 \%$ & -1.62 & -2.57 & -3.12 \\
\hline
\end{tabular}

\section{Tests of Cointegration and Causality}

The idea that a variable is integrated can be extended to two variables and if both variables are integrated one may ask if they are cointegrated. Specifically, if two time series, $\mathrm{X}_{\mathrm{t}}$ and $\mathrm{Y}_{\mathrm{t}}$, are both nonstationary in levels but stationary in the first difference, it is said that variables, $\mathrm{X}_{\mathrm{t}}$ and $\mathrm{Y}_{\mathrm{t}}$, are $\mathrm{I}(1)$. Cointegration represents a long-run equilibrium relationship between two variables. The intuition behind cointegration is that beyond the random walk followed by each variable such randomness preserves a relationship between the two variables. Engle and Granger (1987) propose several methods to test for cointegration between two time series. Their methods have been generalized by Johansen (1991, 1995) who examines long-run equilibrium relationships among several variables instead of just pairwise. In our case we wish to investigate what if any long-term relationships exist among oil, gold and the euro. Thus, we perform a three-variable cointegration test following the Johansen cointegration methodology.

Tables 2 and 3 summarize the results of the Johansen cointegration test. We fail to reject the hypothesis of no cointegration among $\ln$ oil, ln gold and $\ln$ euro at the 0.05 critical value. Several specifications were tested, and none rejected the "no cointegration" hypothesis. This is surprising in view of the fact that these three markets respond to inflationary expectations. Shorter period equilibrium relationships may exist for all three variables or equilibrium relationships may exist between pairs of these variables. 
Table 2

Johansen Cointegration Trace Statistic Test

Sample (adjusted): Jan 4th, 2000 to Dec 31st, 2007

Included observations: 2026 after adjustments

Trend assumption: Linear deterministic trend (restricted constant)

Lags interval (in first differences): 1 to 4

Series: ln Oil, ln Gold, ln Euro

Unrestricted Cointegration Rank Test (Trace)

\begin{tabular}{|c|c|c|c|c|}
\hline $\begin{array}{c}\text { Hypothesized } \\
\text { No. of CE(s) }\end{array}$ & Eigenvalue & $\begin{array}{c}\text { Trace } \\
\text { Statistic }\end{array}$ & $\begin{array}{c}0.05 \\
\text { Critical Value }\end{array}$ & Prob.* \\
\hline None & 0.007185 & 20.51677 & 29.79707 & 0.3885 \\
At most 1 & 0.002593 & 5.908294 & 15.49471 & 0.7064 \\
At most 2 & 0.00032 & 0.648898 & 3.841466 & 0.4205 \\
\hline
\end{tabular}

Trace test indicates no cointegration at the 0.05 level

*MacKinnon-Haug-Michelis (1999) p-values

Table 3

Johansen Cointegration Maximum Eigenvalue Statistic Test

Sample (adjusted): Jan 4th, 2000 to Dec 31st, 2007

Included observations: 2026 after adjustments

Trend assumption: Linear deterministic trend (restricted constant)

Lags interval (in first differences): 1 to 4

Series: ln Oil, ln Gold, ln Euro

Unrestricted Cointegration Rank Test (Maximum Eigenvalue)

\begin{tabular}{|c|c|c|c|c|}
\hline $\begin{array}{c}\text { Hypothesized } \\
\text { No. of CE(s) }\end{array}$ & Eigenvalue & $\begin{array}{c}\text { Max-Eigen } \\
\text { Statistic }\end{array}$ & $\begin{array}{c}0.05 \\
\text { Critical Value }\end{array}$ & Prob.* \\
\hline None & 0.007185 & 14.60848 & 21.13162 & 0.3173 \\
At most 1 & 0.002593 & 5.259396 & 14.2646 & 0.7088 \\
At most 2 & 0.00032 & 0.648898 & 3.841466 & 0.4205 \\
\hline
\end{tabular}

Max-eigenvalue test indicates no cointegration at the 0.05 level *MacKinnon-Haug-Michelis (1999) p-values 
However, the evidence presented in Tables 2 and 3 indicates that for our entire sample, $\ln$ oil, ln gold and ln euro are not cointegrated. One way to explain the lack of cointegration among oil, gold and the euro is the fact that our very long sample of 2000-07 includes at least three distinctive subperiods. During the long period of 2001-07, the U.S. economy was driven by deflationary expectations in 2000-02 due to the bursting of the internet bubble and the recession that followed; then inflationary expectations were very low during the recovery in 2002-2004. Finally, inflationary expectations increased during the 2005-07 period with the housing bubble. Thus when the entire sample of 2000-07 is taken into account the "no cointegration" null hypothesis is not rejected. This implies that we do not have stable longrun equilibrium relationships among these three variables. It may be possible that cointegration holds for certain subsamples.

Now that the three-variable cointegration methodology cannot reject the nocointegration among oil, gold and the euro null hypothesis, we have two choices. One option is to stop further time series investigations. Another is to proceed with the standard procedure of time series methodology and investigate Granger causality. In view of our finding of no cointegration we hypothesize that causality is not present since the variables do not have a stable longrun equilibrium among themselves. To test this hypothesis we perform two causality tests. There is a simple two-variable causality and the more general several variable causality test. We say that the time series, $\mathrm{Y}_{\mathrm{t}}$, "causes" another time series, $X_{t}$, if the current value of $X$ can be predicted better by using past values of $\mathrm{Y}$ than by not doing so, considering also other relevant information, including past values of X. Table 4 confirms, as expected, that there is no pairwise causality. 
Table 4

\begin{tabular}{|l|l|l|l|}
\hline Null Hypotheses & & F-Statistic & Probability \\
\hline LnGold does not Granger Cause & LnEuro & 1.9344 & 0.1021 \\
\hline & LnOil & 2.1757 & 0.0694 \\
\hline LnOil does not Granger Cause & LnGold & 0.3913 & 0.8150 \\
\hline & LnEuro & 0.4259 & 0.7900 \\
\hline LnEuro does not Granger Cause & LnGold & 2.0103 & 0.0906 \\
\hline & LnOil & 1.5370 & 0.1888 \\
\hline
\end{tabular}

Pairwise Granger causality has been generalized by Hsiao $(1981,1982)$ and Giannini and Mosconi (1992) by extending a two variable VAR into a three-variable VAR. The three-variable VAR on ln oil, ln gold and ln euro has automatic lags specification based on Akaike's criterion. Hsiao's method follows a two-step procedure to determine the optimum lag length and also the direction of causality. Table 5 confirms that no causation among the three variables (see chi-sq statistic for All in Table 5) can be detected. Pairwise causation also does not exist except in the case of gold and the euro. The hypothesis that the euro does not cause gold cannot be rejected.

\section{Table 5}

VAR Granger Causality/Block Exogeneity Wald Tests

Sample: $1 / 04 / 2000$ 12/31/2007

Included observations: 2026

Dependent variable: LN_EURO

\begin{tabular}{cccc}
\hline \hline Excluded & Chi-sq & df & Prob. \\
\hline \hline LN_GOLD & 9.892346 & 5 & 0.0783 \\
LN_OIL & 5.172257 & 5 & 0.3952 \\
\hline \hline All & 12.81762 & 10 & 0.2340
\end{tabular}


Dependent variable: LN_GOLD

\begin{tabular}{cccc}
\hline \hline Excluded & Chi-sq & df & Prob. \\
\hline \hline $\begin{array}{c}\text { LN_EURO } \\
\text { LN_OIL }\end{array}$ & 12.03545 & 5 & 0.0343 \\
\hline \hline All & 1.758522 & 5 & 0.8814 \\
\hline \hline
\end{tabular}

Dependent variable: LN_OIL

\begin{tabular}{cccc}
\hline \hline Excluded & Chi-sq & df & Prob. \\
\hline \hline LN_EURO & 3.258233 & 5 & 0.6602 \\
LN_GOLD & 5.418304 & 5 & 0.3670 \\
\hline \hline All & 12.12205 & 10 & 0.2770 \\
\hline \hline
\end{tabular}

The results of this section indicate that for the large number of observations in our sample, 2031 observations to be exact, covering the 2000-2007 period, the main conclusion of time series analysis is that these three markets are efficient in the semistrong sense, where all publically available information is quickly incorporated in the prices. General equilibrium considerations play an important role and there may be linkages among these three markets, perhaps over short periods but none are detected for the longrun. These three markets appear independent with no evidence of cointegration and therefore with no statistical significance to identify clear causation among these variables. Therefore the various very short-term arbitrage strategies that are occasionally reported in the financial press among oil, gold and the euro as reflecting expected inflation and thus moving in similar trends find no clear evidence from time series methodology. 


\section{Neural Network Methodology}

In this section we employ a neural network methodology to further explore the relationships among oil, gold and the euro. Neural network methods offer a much larger menu of potential relationships among these three variables than the time series approach. In view of the fact that neural network methods uncover nonlinear relationships that need not be financially or economically motivated, the usual criterion of the effectiveness of the neural network methodology is its success in predictability.

If any of these variables cause the others, then we should be able to forecast the values of one using information from lags of itself and the others. We first selected a random 10 percent of the data from each year of the data set from 2000 through 2007 to use as a holdout testing set. We then forecasted the each of the three variables, ln gold, $\ln$ oil, and ln euro.

All data is expressed as natural logarithms to overcome the issue of nonstationarity. Thus, for example, when the target variable is the natural logarithm of the euro, then the inputs are the lagged natural logs for 5 days of the euro, gold, and oil. Thus there are 15 inputs for each forecast. The neural network models were run using the SPSS package Clementine. Each was structured with one input layer of 15 nodes, one hidden layer of 18 nodes, and one output layer of one node. After training the network, Clementine generates not only a model to be used for forecasting, but also a list of variable importance for the inputs. This list assigns a value to each input indicating the relative amount the target variable changes when changes occur in the input variable. The variable importance values over all variables sum to 1 for each network. 
Table 6 shows the mean absolute error in forecasting for the training and testing sets for each of the three networks. This error measure was stable from training to testing sets, indicating robust models that will do as well on unseen data as on data used for training. To give context to these values, the average values of the target variables over the training set are also given.

\section{Table 6}

Mean absolute error for training and testing sets

\begin{tabular}{|l|c|c|c|}
\hline & Ln euro & Ln oil & Ln gold \\
\hline Training & .00504 & .0204 & .008 \\
\hline Testing & .00544 & .0202 & .0078 \\
\hline Average variable value & 0.1076 & 3.6533 & 5.9930 \\
\hline
\end{tabular}

All variable lags were used in each of the models as inputs. The most significant variable in each model was the previous day's value of the target variable. However, all variables had some impact. In Table 7, we sum the values of the five inputs of each variable type (lags of $\ln$ oil, ln euro, and $\ln$ gold).

\section{Table 7}

Effect of variable types on the dependent variable

\begin{tabular}{|c|c|c|}
\hline \multirow{3}{*}{ Dependent Variable } & Input Variables & $\begin{array}{c}\text { Sum of Relative } \\
\text { Importance Values over 5 lags }\end{array}$ \\
\hline \multirow{3}{*}{$\ln$ gold } & ln gold lags & 0.737 \\
\cline { 2 - 3 } & ln oil lags & 0.154 \\
\cline { 2 - 3 } & ln euro lags & 0.109 \\
\hline \multirow{3}{*}{$\ln$ oil } & ln gold lags & 0.149 \\
\cline { 2 - 3 } & ln oil lags & 0.764 \\
\cline { 2 - 3 } & ln euro lags & 0.087 \\
\hline \multirow{3}{*}{$\ln$ euro } & ln gold lags & 0.242 \\
\cline { 2 - 3 } & ln oil lags & 0.096 \\
\cline { 2 - 3 } & ln euro lags & 0.662 \\
\hline
\end{tabular}


For the network used to forecast ln gold, the lags of ln gold have the most impact, followed by those of $\ln$ oil, then $\ln$ euro. In forecasting ln oil, the ln oil lags have greatest impact, followed by $\ln$ gold, then $\ln$ euro last. In the last network with $\ln$ euro as the dependent variable, the ln euro lags have the greatest relative importance, then ln gold, followed by ln oil. Thus, the non-linear approach of the neural network indicates that it is picking up some amount of influence from the lags of each type for forecasting tomorrow's values.

Further discussion of similar issues using neural networks on these markets is presented in Dunis and Williams (2002), Jamaleh (2002), Binner, Bissoondeeal, Elger, Gazely, and Mullineux (2005), and Krichene (2008a, 2008b).

\section{Conclusions}

The U.S. economy has experienced dramatic increases during the pre- financial crisis period of 2000-2007 in the price of oil and its related products such as gasoline. Fundamental analysis attributes these changes to substantial global increases in the demand for oil, particularly from emerging economies such as China, India and Brazil with major disruptions in the supply of oil due to the war in Iraq and the political problems in Venezuela.

In this paper we first offer a review of the markets for oil and gold prior to the the creation of the euro. This analysis demonstrates that the oil and gold markets had limited inter-relationships between them. Since the euro did not exist prior to 1999, it did not play any role. In contrast, during the 2000-2007 period, gold, oil and the euro markets appear to have moved together. 
To analyze inter-relationships among the price behavior of gold, oil and the euro, we formulate certain hypotheses: (1) these three markets follow standard random walk behaviors meaning that these markets are efficient with available information rapidly being incorporated in the daily prices; (2) these three markets are linked together; (3) oil increases contribute to inflationary expectations and may cause increases in the price of gold and increases in the price of the euro; (4) general inflationary expectations expressed by an increase in the price of gold or the price of the euro may also cause increases in the price of oil; finally (5) changes in the price of the euro influence the price of gold; this happens because the price of euro and the price of gold are both expressed in U.S. dollars.

We use two methodologies to enrich the testing of these hypotheses. We perform various time series tests and neural network analysis. The time series analysis confirms that the first differences of the log prices are stationary. Since these three markets follow random walks we conclude that these markets are efficient. We do not find a relationship connecting all three markets. The Johansen test that these three markets are independent cannot be rejected. We also cannot find much in the form of causality. There is limited statistical evidence that gold is influenced by the euro.

The evidence from the time series methodology is enriched by the neural networks forecasting methodology that shows the prediction of oil prices using both the gold price and the euro as inputs with up to five lags in each variable as having a lower mean square error than the forecasts of either the price of gold or that of the euro. In other words, gold, the euro and their lagged values as well as oil lagged values predict very well the price of oil. The second finding from the neural network analysis shows that oil 
and its lagged values are inputs in predicting both the values of the euro and gold. Thus we confirm the existence of feedback not found in time series analysis. The best predicting variable for the euro, in addition to lagged values of the euro is gold not found in the time series analysis.

The overall conclusion is that oil, gold, and the euro are important global markets that challenge financial economists to articulate fundamental relationships among them. There are of course market conditions of supply and demand for each market but there are also common inflationary expectations that influence concurrently all three markets. Our analysis for the period 2000-2007 shows that the oil market is clearly influenced by both the euro and gold markets, in addition to its own fundamentals of supply and demand. Furthermore, movements in the price of oil influence both the price of gold and the euro. When the euro strengthens against the U.S. dollar, often the price of gold increases. However, there is sufficient evidence to indicate that no strong longrun equilibrium relationships exist among these variables and both methodologies indicate that each variable is driven primarily by its own lagged values. 


\section{Bibliography}

Aliber, Robert (1966) The Future of the dollar as an international currency New York: Frederick Praeger Publishers

Angeloni, Ignazio, Kashyap, Anil K., Mojon, Benoit and Terlizzese, Daniele (2003), Monetary transmission in the euro area: does the interest rate channel explain it all?" NBER Working Paper No. W9984, September.

Barro, Robert J. (1979), Money and the price level under the gold standard," Economic Journal 89:12-33.

Bernanke, Ben, Gertler, Mark, and Watson, Mark (1997), Systematic monetary policy and the effects of oil shocks Brookings Papers on Economic Activity 1:91-157.

Bhar, Ramaprasad and Malliaris, A.G. (1998), Volume and volatility in foreign currency futures markets Review of Quantitative Finance and Accounting 10:285-302.

Binner, Jane M., Bissoondeeal, Rakesh K., Elger, Thomas, Gazely, Alicia M. and Mullineux, Andrew W. (2005), "A comparison of linear forecasting models and neural networks: an application to Euro inflation and Euro Divisia," Applied Economics, vol. 37, pp. 665-680.

Blanchard, Olivier J. and Gali, Jordi (2007), "The Macroeconomic Effects of Oil Price Shocks: Why are the 2000s so Different from the 1970s?" MIT Department of Economics Working Paper No. 07-21, August 18.

Bordo, Michael D. (1981), "The Classical Gold Standard: Some Lessons for Today," Federal Reserve Bank of St. Louis Review, May, vol. 63, pp. 2-17.

Bordo, Michael D., and Kydland, Finn E. (1995), “The Gold Standard as a Monetary Rule," Explorations in Economic History, vol. 32, pp. 423-464.

Bordo, Michael D., Dittmar, Robert D. and Gavin, William T. (2007), "Gold, Fiat Money and Price Stability," Federal Reserve Bank of St. Louis Working Paper No. 2003-014D, May.

Bordo, Michael D. and James, Harold (2008), "A Long Term Perspective on the Euro," NBER Working Paper No. W13815, February.

Canjels, Eugene, Prakash-Canjels, Gauri, and Taylor, Alan M. (2004) "Measuring Market Integration: Foreign Exchange Arbitrage and the Gold Standard, 1979- 1913," Review of Economics and Statistics, vol. 86, pp. 868-882. 
Carpenter, C. (2004), "Gold May Rise as Dollar Falls, Oil Price Rallies, Survey Shows," Bloomberg, July 18, 2004.

Chinn, Menzie David and Frankel, Jeffrey A. (2008), "Why the Euro Will Rival the Dollar," International Finance, vol. 11, pp. 49-73.

Diba, Behzad and Grossman, Herschel I. (1984), "Rational Bubbles in the Price of Gold," NBER Working Paper Series, vol. w1300, March.

Dickey, D. A., and Fuller, W. A. (1979), "Distribution of the Estimators for Autoregressive Time Series with a Unit Root," Journal of the American Statistical Association, vol. 74, pp. 427-431.

Dunis, Christion, and Williams, Mark. (2002), "Modelling and Trading the EUR/USD Exchange Rate: Do Neural Network Models Perform Better?" Derivatives Use, Trading \& Regulation, vol. 8, pp. 211-239.

Eichengreen, Barry (1992), "Golden Fetters: The Gold Standard and the Great Depression, 1919-1939,” New York: Oxford University Press.

Eichengreen, Barry J. (2007), "The Breakup of the Euro Area," NBER Working Paper No. W13393, September.

Elekdag, Selim Ali, Lalonde, Rene, Laxton, Douglas, Muir, Dirk and Pesenti, Paolo A. (2008), "Oil Price Movements and the Global Economy: A Model-Based Assessment," NBER Working Paper No. W13792, February.

Enders, Walter (2010), Applied Econometric Time Series, Third Edition, John Wiley \& Sons, Hoboken, New Jersey.

Engle, R. F., and Granger, C. W. J. (1987), "Cointegration and Error Correction Representation, Estimation and Testing,” Econometrica, vol. 55, pp. 251-276.

Finn, Mary G. (2000), "Perfect Competition and the Effects of Energy Price Increases on Economic Activity," Journal of Money Credit and Banking, vol. 32, pp. 400-416.

Fujiki, Hiroshi (2003), "A Model of the Federal Reserve Act under the International Gold Standard System," Journal of Monetary Economics, vol. 50, pp. 1333-50.

Giannini, C., and Mosconi, R. (1992), "Non-Causality in Cointegrated Systems: Representation, Estimation and Testing," Oxford Bulletin of Economics and Statistics, vol. 54, pp. 399-417.

Goodfriend, Marvin (1988), "Central Banking under the Gold Standard," Carnegie Rochester Conference Series on Public Policy, Spring, vol. 29, pp. 85-124. 
Hamilton, James (1983), "Oil and the Macroeconomy Since World War II," Journal of Political Economy, April, pp. 228-248.

Hamilton, James (1996), "This is What Happened to the Oil Price Macroeconomy Relationship," Journal of Monetary Economics, October, vol. 38, pp. 215-220.

Hanke, S. (2008), "It's All the Fed's Fault,” Forbes, 11.10.08.

Henning Steven L. and Shaw Wayne (2000) Future stock performance of oil and gas firms conditional on the imputed value of reserves Review of Quantitiative Finance and Accounting 15:127-135.

Herrera, Ana Maria and Pesavento, Elena (2007), "Oil Price Shocks, Systematic Monetary Policy, and the Great Moderation," Michigan State University, unpublished manuscript.

Hooker, Mark A. (1996), "What Happened to the Oil Price Macroeconomy Relationship?" Journal of Monetary Economics, vol. 38, pp. 195-213.

Hooker, Mark A. (2002), "Are Oil Shocks Inflationary? Asymmetric and Nonlinear Specifications versus Changes in Regime," Journal of Money, Credit and Banking, vol. 34, pp. 540-561.

Hsiao, C. (1981), "Autoregressive Modeling and Money Causality Detection”, Journal of Monetary Economics, vol. 7, pp. 85-106

Hsiao, C., (1982), "Autoregressive Modeling and Causal Ordering of Econometric Variables", Journal of Economic Dynamics and Control, vol. 4, pp.243259.

Jamaleh, Asmara (2002), "Explaining and forecasting the euro/dollar exchange rate through a non-linear threshold model," The European Journal of Finance, vol. 8, pp. 422-448.

Johansen, S. (1991), "Estimation and Hypothesis Testing of Cointegrating Vectors in Gaussian Vector Autoregressive Models", Econometrica, vol. 59, pp. 1551-1580.

Johansen, S., (1995), Likelihood Based Inference in Cointegrated Vector Autoregressive Models, New York: Oxford University Press.

Lin, William and Chang-Wen Duan (2007) Oil convenience yields under demand/supply shock Review of Quantitative Finance and Accounting, 28:203-225. 
Kilian, Lutz (2008), "A Comparison of the Effects of Exogenous Oil Supply Shocks on Output and Inflation in the G7 Countries," Journal of the European Economic

Association, vol. 6, pp. 78-121.

Kondonassis, A., C. Paraskevopoulos and A.G. Malliaris (2007), "The Future of the U.S. Dollar and Its Competition With the Euro," European Research Studies, vol. 10, pp. 97110.

Krichene, Noureddine (2008a), "Crude Oil Prices: Trends and Forecast," IMF Working Paper, May.

Krichene, Noureddine (2008b), "Recent Inflationary Trends in World Commodities Markets," IMF Working Paper, May.

MacKinnon, J., A. Haug and L. Michelis (1999), "Numerical Distribution Functions of Likelihood Ratio Tests for Cointegration", Journal of Applied Econometrics, vol. 14, pp. 563-577.

Mileva, Elitza and Siegfried, Nikolaus (2007), "Oil Market Structure, Network Effects and the Choice of Currency for Oil Invoicing," European Central Bank, Occasional Paper Series, No. 77, December.

Nakov, Anton and Pescatori, Andrea (2007), "Oil and the Great Moderation," Federal Reserve Bank of Cleveland, Working Paper 07-17, November.

Portes, Richard and Rey, Helene M. (1998), "The Emergence of the Euro as an International Currency," NBER Working Paper No. W6424, February. 